\title{
KONSUMSI AIR KEMASAN DI INDONESIA
}

\begin{tabular}{|c|}
\hline Lulu Lestari \\
Badan Pusat Statistik Kabupaten Cilacap \\
lululestari@bps.go.id
\end{tabular}

Diterima: Agustus 2020; Disetujui: Maret 2021

\begin{abstract}
Water is primary need for human. People need at least 2 litres of water a day for drinking. Fulfilment of these needs very depend on the availability of a decent drinking water source. Based on data of Statistics Indonesia, people who consume bottled water in Indonesia reached 36 percent in 2018. It was significantly increase 3 times compared 10 years before. This increase needs to be watched out because bottled water is an unsustainable source of drinking water. In the following research, a model was formed that can predict the factors that influence bottled water consumption. The model was carried out using Structural Equation Modelling Partial Least Square (SEM PLS) analysis. There are two steps in SEM analysis, first making measurement model than structural model. The results from measurement model: demographic factor is measured by growth of population and urbanization, income factor measured by expenditure per capita per month, social culture factor measured by Human Development Index (HDI) and percentage of people who watch television. Based on structural model, all of the factors (demography, income, social culture) affect bottled water consumption in Indonesia. DKI Jakarta, Kepulauan Riau, Kalimantan Timur, Kalimantan Utara, and Kepulauan Bangka Belitung are the provinces which predicted have significant increasing in bottled water consumption.
\end{abstract}

Keyword: bottled water, Indonesia, SEM PLS.

Abstraksi. Air minum merupakan kebutuhan manusia. Manusia membutuhkan setidaknya dua liter air untuk minum setiap harinya. Pemenuhan terhadap kebutuhan tersebut sangat bergantung pada ketersediaan sumber air minum yang layak. Berdasarkan data Badan Pusat Statistik (BPS), penggunaan air kemasan di Indonesia pada tahun 2018 mencapai 36 persen. Angka tersebut meningkat 3 kali lipat dibandingkan sepuluh tahun sebelumnya. Peningkatan tersebut perlu diwaspadai mengingat air kemasan merupakan sumber air minum yang tidak berkelanjutan. Dalam penelitian berikut, dibentuk model yang dapat memprediksi faktor-faktor yang mempengaruhi konsumsi air kemasan. Pemodelan dilakukan dengan menggunakan analisis Structural Equation Modeling Partial Least Square (SEM PLS). Terdapat dua tahapan dalam analisis SEM yaitu tahap pembentukan model pengukuran dan model struktural. Pada tahap pembentukan model pengukuran diperoleh hasil: faktor demografi diukur melalui pertumbuhan penduduk dan urbanisasi, faktor pendapatan masyarakat diukur lewat pengeluaran masyarakat per kapita per bulan, faktor sosial budaya diukur melalui Indeks Pembangunan Manusia (IPM) dan persentase masyarakat yang menonton televisi. Berdasarkan hasil pengolahan model struktural didapatkan kesimpulan bahwa ketiga faktor dalam penelitian yaitu faktor demografi, faktor pendapatan masyarakat, dan faktor sosial budaya mempengaruhi konsumsi air kemasan di Indonesia. DKI Jakarta, Kepulauan Riau, Kalimantan Timur, Kalimantan Utara, dan Kepulauan Bangka Belitung merupakan provinsi-provinsi yang diprediksi memiliki peningkatan signifikan dalam konsumsi air kemasan berdasarkan model yang terbentuk.

Kata kunci: air kemasan, Indonesia, SEM PLS. 


\section{PENDAHULUAN}

Air adalah komponen yang penting bagi kehidupan manusia. Tidak akan ada kehidupan seandainya di bumi ini tidak ada air, karena air merupakan kebutuhan utama bagi proses kehidupan (Susana, 2003). Manfaat air yang paling utama bagi manusia adalah untuk minum. Manusia membutuhkan setidaknya dua liter air setiap harinya untuk minum. Pada tahun 2018 jumlah penduduk Indonesia mencapai 265 juta jiwa (Badan Pusat Statistik, 2015) dimana kebutuhan air minum sehari dapat mencapai 530 juta liter. Bisa dibayangkan berapa kebutuhan air minum untuk sebulan, setahun, atau beberapa dekade mendatang.

Berdasarkan Peraturan Menteri Kesehatan Republik Indonesia Nomor 492/MENKES/PER/IV/2010 air minum yang aman dikonsumsi bagi kesehatan adalah yang memenuhi persyaratan fisika, mikrobiologis, kimiawi, dan radioaktif. Air layak minum tersebut dapat melalui proses pengolahan maupun tidak. Air yang layak untuk diminum diperoleh dari sumber air yang layak pula. Menurut Badan Pusat Statistik (BPS) sumber air minum yang layak adalah berasal dari: ledeng/ keran, keran umum, hydrant umum, terminal air, penampungan air hujan (PAH), mata air terlindung, sumur terlindung, sumur bor/ sumur pompa yang jaraknya minimal 10 meter dari pembuangan kotoran, penampungan limbah, dan pembuangan sampah.

Selain sumber di atas dikategorikan sebagai sumber air minum yang tidak layak, contohnya: air kemasan, air dari penjual keliling, air yang dijual melalui tangki, air sumur tidak terlindung, dan mata air tidak terlindung. Air kemasan maupun air yang berasal dari penjual dikategorikan tidak layak dari sisi akses keberlanjutannya. Masyarakat yang bergantung pada sumber air minum tersebut rentan untuk mengalami kelangkaan karena air dijadikan sebagai komoditas perdagangan yang ketersediaannya sesuai dengan kondisi pasar. Pentingnya akses keberlanjutan terhadap sumber air minum juga dituangkan sebagai tujuan keenam dalam Sustainable Development Goals (SDGs). Pada tahun 2030 diharapkan seluruh penduduk Indonesia dapat mencapai akses air minum layak yang aman dan terjangkau.

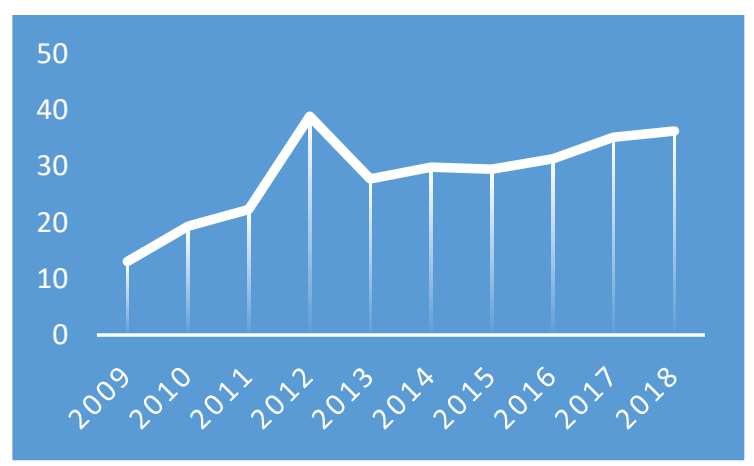

Gambar 1. Persentase rumah tangga di Indonesia yang menggunakan sumber air minum utama berupa air kemasan/air isi ulang, 2009-2018

Sumber: BPS, 2019

Meskipun masuk dalam kategori yang tidak layak dari sisi akses keterjangkauan, air kemasan malah menjadi salah satu alternatif bagi masyarakat untuk memenuhi kebutuhan minum. Berdasarkan data BPS, konsumsi air kemasan dalam satu dekade terakhir meningkat pesat. Pada tahun 2009 sekitar 13 persen penduduk Indonesia mengonsumsi air kemasan dan pada tahun 2018 mencapai lebih dari 36 persen (gambar 1). Asosiasi Perusahaan Air Minum dalam Kemasan (Aspadin) mencatat volume penjualan air kemasan di Indonesia mencapai 3,8 juta liter di tahun 2018, tumbuh sekitar 8 persen dibandingkan tahun sebelumnya.

Pertumbuhan industri air kemasan di Indonesia dimulai sejak tahun 1973. Pada tahun 1991 Aspadin berdiri dan menaungi 
36 perusahaan air minum. Volume penjualan saat itu baru mencapai 6 juta liter setahun. Tahun 2005 konsumsi air kemasan mulai berkembang. Sekitar 4 persen penduduk Indonesia menggunakan air kemasan sebagai sumber air minum utama. Sekarang, mengonsumsi air kemasan diasosiasikan sebagai gaya hidup sehat. Banyak media yang mengiklankan bahwa minum air kemasan merupakan cara modern untuk mencapai hidup sehat. Air kemasan diklaim lebih higienis dibandingkan air minum yang diolah/ direbus sendiri.

Padahal air kemasan bukan merupakan sumber air minum yang berkelanjutan. Kehadirannya di tengah-tengah masyarakat tidak dapat dijadikan solusi utama untuk mengatasi keterbatasan air minum. Air kemasan muncul sebagai komoditas perdagangan yang hanya dapat dinikmati oleh kalangan tertentu. Pengawasan pemerintah terhadap kualitas air kemasan yang beredar juga belum ketat. Terbukti dengan banyaknya kasus pemalsuan merek dagang, kandungan bakteri, dan sampah kemasan plastik dari produk air kemasan (Tempo, 2018). Beberapa dampak negatif itulah yang harus diwaspadai baik oleh pemerintah pusat maupun pemerintah daerah terkait semakin meningkatnya konsumsi air kemasan sebagai sumber air minum utama keluarga.

Peningkatan konsumsi air kemasan tidak hanya terjadi di Indonesia, tetapi di berbagai negara lain. Penelitian di British Columbia, Kanada menunjukkan bahwa konsumsi air kemasan dipengaruhi oleh faktor demografi (umur, jenis kelamin, pendidikan, pendapatan rumah tangga), wilayah tempat tinggal, dan jenis sumber air (Jones et al, 2007). Perubahan demografi, jenis kelamin, dan pendidikan sangat berpengaruh terhadap kebiasaan konsumsi masyarakat Kanada sehingga air kemasan memegang proporsi terbesar sebagai sumber air minum utama di negara tersebut (Pintar et al, 2009).

Selain itu, persepsi masyarakat tentang kualitas air kemasan yang lebih baik dibandingkan sumber air minum lainnya ikut mendorong peningkatan konsumsi komoditas tersebut. Persepsi akan membentuk baik perilaku individu maupun perilaku sosial dalam memilih sumber air yang digunakan (Stoler et al, 2015). Faktor sosial memiliki pengaruh tertinggi dalam keputusan konsumsi air minum masyarakat Bangladesh (Mosler et al, 2010).

Tujuan dari penelitian yaitu untuk mengetahui faktor-faktor yang mempengaruhi konsumsi air kemasan di Indonesia dan mengidentifikasi provinsi yang diprediksi bergantung terhadap air kemasan/air isi ulang sebagai sumber air minumnya.

Penelitian terhadap konsumsi air kemasan sangat bermanfaat untuk mengidentifikasi faktor apa saja yang mempengaruhi perubahan pola masyarakat tersebut. Apakah perubahan tersebut memang benar karena keterbatasan sumber air minum yang layak karena perubahan demografi yang sangat dinamis atau hanya karena pengaruh dari persepsi modernisasi. Dari hasil penelitian juga akan diperoleh identifikasi wilayah yang memiliki resiko ketergantungan terhadap air kemasan sebagai sumber baku air minum masyarakatnya.

Pengembangan dari sisi ilmiah juga diharapkan dari penelitian ini dengan penggunaan metode analisis Structural Equation Modelling Partial Least Square (SEM PLS). Metode ini digunakan untuk mengkaji permasalahan dengan unit analisis provinsi yang jumlahnya relatif kecil (34 provinsi). Selain itu, pengukuran indikator 
dengan konsep reflektif dan konstruktif digabungkan untuk memperkuat posisi indikator yang berpengaruh terhadap variabel penelitian.

\section{Kajian Teori}

Konsumsi adalah segala kegiatan yang dipergunakan dengan tujuan untuk mengambil kegunaan pada suatu produk. Teori konsumsi Keynes menyatakan bahwa jumlah pengeluaran konsumsi sangat berhubungan erat dengan pendapatan yang dimiliki. Semakin tinggi pendapatan maka semakin besar pula pengeluaran untuk kegiatan konsumsi. Pola yang serupa terjadi untuk konsumsi air kemasan. Semakin tinggi pendapatan seseorang maka semakin besar pula proporsi pendapatannya yang digunakan untuk mengonsumsi air kemasan (Delina \& Dasinaa, 2016).

Menurut Dusenberry, selain faktor pendapatan, terdapat hal lain yang juga berpengaruh terhadap pola konsumsi seseorang yaitu besarnya konsumsi orang lain (interdependent factor). Seseorang dengan pengeluaran konsumsi sederhana akan mengubah pola konsumsinya jika tinggal di daerah yang konsumsi masyarakatnya tinggi (konsumsi yang tinggi mengindikasikan bahwa masyarakat tersebut sejahtera). Perubahan tersebut dilakukan untuk memperkuat status sosial seseorang dalam masyarakat. Masyarakat dengan status sosial yang tinggi cenderung memiliki kualitas hidup yang lebih baik dari sisi ekonomi, pendidikan, maupun kesehatan. Kelompok masyarakat tersebut memiliki anggapan bahwa mengonsumsi air kemasan lebih sehat dibandingkan air biasa (Chen et al, 2012).

Perubahan kondisi sosial juga turut berpengaruh terhadap pola konsumsi masyarakat. Menurut Warren Thompson perubahan sosial dapat diukur melalui perubahan demografi yang meliputi kelahiran, kematian, dan migrasi. Kelahiran dan kematian menentukan tingkat pertumbuhan penduduk di suatu wilayah. Selain itu, migrasi penduduk dari desa ke kota (urbanisasi) juga ikut mempengaruhi pola konsumsi masyarakat (Regmi \& Dyck, 2015).

Berdasarkan penjelasan teori tersebut maka secara umum penelitian ini bertujuan untuk mengkaji apa saja faktor yang mempengaruhi pola konsumsi air kemasan di Indonesia. Pola konsumsi air kemasan dideskripsikan melalui tiga faktor yaitu: faktor pendapatan masyarakat, faktor sosial budaya, dan faktor demografi. Faktor pendapatan masyarakat tercermin melalui rata-rata pengeluaran rumah tangga per kapita per bulan. Faktor sosial budaya tercermin melalui kualitas hidup masyarakat yang diukur melalui Indeks Pembangunan Manusia (IPM) dan kecenderungan masyarakat menonton televisi (sebagai media untuk mendapatkan informasi). Faktor demografi diukur melalui perubahan indikator pertumbuhan penduduk dan tingkat urbanisasi. Hubungan ketiga faktor tersebut terhadap pola konsumsi air kemasan diperlihatkan pada gambar 2.

Hipotesis dalam penelitian ini ada tiga yaitu: faktor demografi mempengaruhi konsumsi air kemasan di Indonesia, faktor pendapatan masyarakat mempengaruhi konsumsi air kemasan di Indonesia, dan faktor sosial budaya mempengaruhi konsumsi air kemasan di Indonesia. 


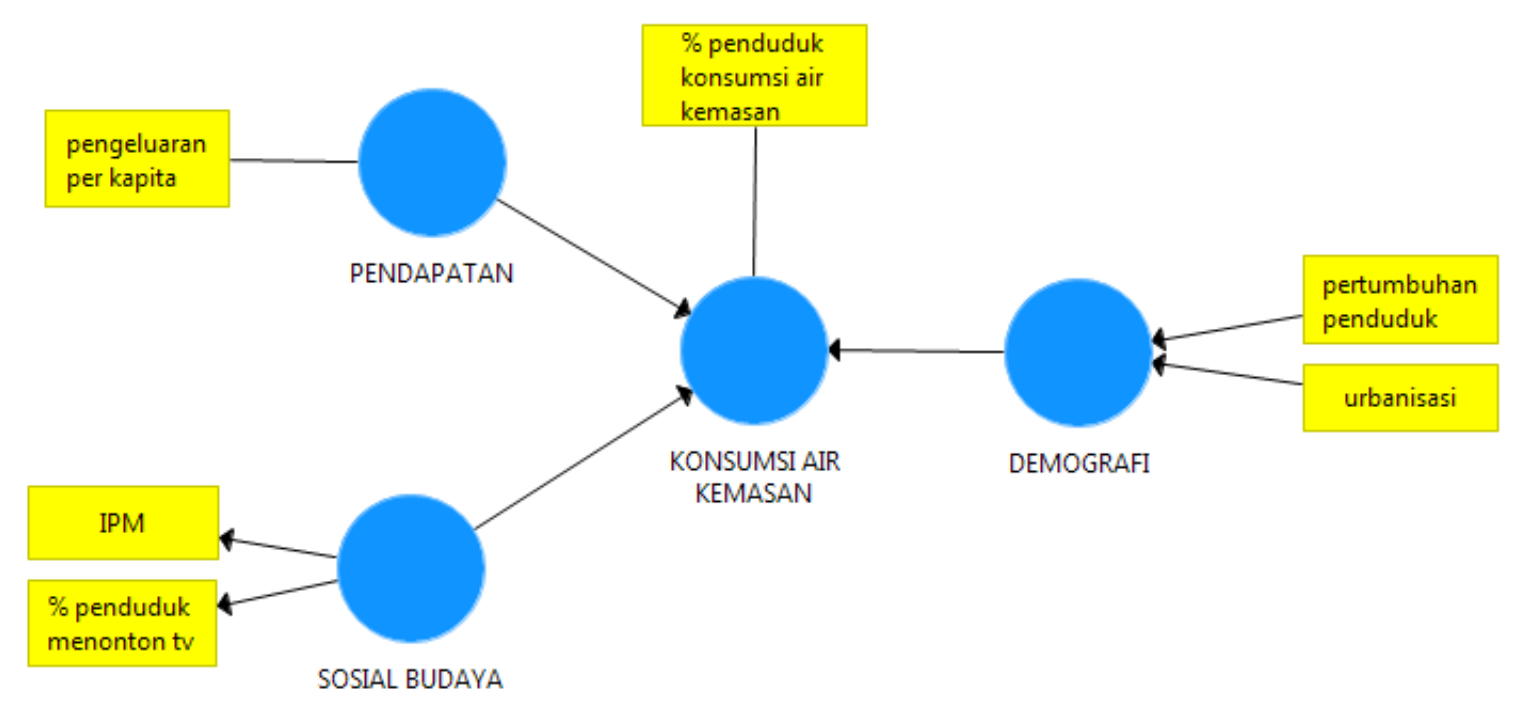

Gambar 2. Kerangka Penelitian

Sumber: Delina \& Dasinaa (2016), Chen et al. (2012), Regmi \& Dyck (2015)

\section{METODE PENELITIAN}

Subjek penelitian dalam hal ini adalah seluruh provinsi yang ada di Indonesia sejumlah 34 provinsi. Sumber data yang digunakan berasal dari data BPS. Data pertumbuhan penduduk dan urbanisasi berasal dari data proyeksi hasil Sensus Penduduk tahun 2010. Untuk data pengeluaran per kapita, IPM, dan persentase penduduk yang menonton televisi berasal dari Survei Sosial Ekonomi Nasional (SUSENAS).

Analisis data menggunakan metode SEM PLS. Analisis tersebut mengevaluasi model dari pembentukan variabel (hubungan indikator dengan variabel) sampai dengan hubungan antar variabel dalam penelitian. Iterasi pada model dilakukan dengan menggunakan metode bootstrapping mengingat keterbatasan unit penelitian (34 provinsi).

Keterbatasan tersebut juga mengakibatkan model yang dipilih tidak mengindahkan asumsi normalitas yang berlaku sehingga model yang dihasilkan berupa model nonparametrik (Hair et al., 2014). Meskipun tidak mengikuti distribusi normal penggunaan analisis SEM PLS semakin berkembang karena asumsi yang digunakan relatif lebih fleksibel ketimbang metode analisis lainnya (Hair et al, 2011). SEM PLS digunakan saat tujuan penelitian ialah memprediksi dan mengembangkan teori (Lowry dan Gaskin, 2014).

Langkah-langkah pemodelan dengan SEM PLS adalah sebagai berikut (Jaya, Sumertajaya; 2008): merancang model struktural (hubungan antar variabel), merancang model pengukuran (hubungan indikator terhadap variabel, apakah bersifat reflektif atau formatif), mengonstruksi diagram jalur (menggambarkan hubungan struktural dan pengukuran dalam sebuah diagram), konversi diagram jalur ke sistem persamaan, estimasi dengan metode kuadrat terkecil (least square methods). Proses perhitungan dilakukan dengan cara iterasi sampai terjadi kondisi konvergen yaitu dengan: uji kecocokan model baik model struktural maupun pengukuran kemudian melakukan pengujian hipotesis.

\section{HASIL DAN PEMBAHASAN}

Persamaan model pengukuran yang dibentuk adalah sebagai berikut: 


$$
\begin{aligned}
& \xi_{1}=\lambda_{x 11} x_{11}+\lambda_{x 12} x_{12}+\delta_{1} \\
& x_{21}=\lambda_{x 21} \xi_{2}+\delta_{2} \\
& x_{31}=\lambda_{x 31} \xi_{3}+\delta_{3} \\
& x_{32}=\lambda_{x 32} \xi_{3}+\delta_{4} \\
& y_{1}=\lambda_{y 1} \eta_{1}+\varepsilon_{1}
\end{aligned}
$$

Persamaan model pengukuran
menunjukkan bahwa indikator-indikator
pengukuran memiliki kecukupan dalam
menilai variabel dalam penelitian. Hasil uji
kecocokan model pengukuran terdapat pada
tabel 1.

Tabel 1.

Uji Kecocokan Model Pengukuran SEM PLS dengan Software Smart PLS 3.3

\begin{tabular}{llll}
\hline \multicolumn{1}{c}{ Variabel } & \multicolumn{1}{c}{ Indikator } & Loading faktor & Galat model \\
\hline Faktor demografi $\left(\xi_{1}\right)$ & $\begin{array}{l}\text { Pertumbuhan penduduk } \\
\left(x_{11}\right)\end{array}$ & $0,79\left(\lambda_{x 11}\right)$ & $\left(\delta_{1}\right)$ \\
& Urbanisasi $\left(x_{12}\right)$ & $0,79\left(\lambda_{x 12}\right)$ & \\
$\begin{array}{l}\text { Faktor pendapatan } \\
\text { masyarakat }\left(\xi_{2}\right)\end{array}$ & $\begin{array}{l}\text { Pengeluaran per kapita per } \\
\text { bulan }\left(x_{21}\right)\end{array}$ & $1\left(\lambda_{x 21}\right)$ & $\left(\delta_{2}\right)$ \\
$\begin{array}{l}\text { Faktor sosial budaya } \\
\left(\xi_{3}\right)\end{array}$ & $\begin{array}{l}\text { IPM }\left(x_{31}\right) \\
\text { Persentase penduduk } \\
\text { menonton tv }\left(x_{32}\right)\end{array}$ & $0,95\left(\lambda_{x 31}\right)$ & $\left(\delta_{3}\right)$ \\
$\begin{array}{l}\text { Konsumsi air minum } \\
\text { kemasan }\left(\eta_{1}\right)\end{array}$ & $\begin{array}{l}\text { Persentase penduduk yang } \\
\text { sumber air minum utama air } \\
\text { kemasan/air isi ulang }\left(y_{1}\right)\end{array}$ & $0,88\left(\lambda_{x 32}\right)$ & $\left(\delta_{4}\right)$ \\
& $\begin{array}{l}\text { Sumber: Hasil pengolahan } S E M ~ \\
\end{array}$ \\
\hline
\end{tabular}

Sumber: Hasil pengolahan SEM PLS

Persamaan model struktural yang $\Gamma_{2}$ : koefisien jalur untuk variabel faktor terbentuk adalah: pendapatan masyarakat

$\eta_{1}=\Gamma_{1} \xi_{1}+\Gamma_{2} \xi_{2}+\Gamma_{3} \xi_{3}+\zeta$

Dimana:

$\eta_{1}$ : konsumsi air minum kemasan

$\Gamma_{1}$ : koefisien jalur untuk variabel faktor demografi

$\xi_{1}$ : variabel faktor demografi

$\xi_{2}$ : variabel faktor pendapatan masyarakat

$\Gamma_{3}$ : koefisien jalur untuk variabel faktor sosial budaya

$\xi_{3}$ : variabel faktor sosial budaya

$\zeta$ : galat pada pemodelan struktural

Hasil pengujian hipotesis hubungan antar variabel ditampilkan pada tabel 2 berikut ini. 
Tabel 2.

Uji Kecocokan Model Struktural SEM PLS dengan Software Smart PLS 3.0

\begin{tabular}{lcccc}
\hline \multicolumn{1}{c}{ Hubungan antar variabel } & $\begin{array}{c}\text { Koefisien } \\
\text { jalur }\end{array}$ & $\begin{array}{c}\text { Standar } \\
\text { deviasi }\end{array}$ & $\begin{array}{c}p \text {-values } \\
(\alpha=5 \%)\end{array}$ & $\begin{array}{c}\text { Uji } \\
\text { hipotesis }\end{array}$ \\
\hline $\begin{array}{l}\text { Faktor demografi -> Konsumsi air } \\
\text { kemasan }\end{array}$ & 0,334 & 0,143 & 0,020 & Signifikan \\
$\begin{array}{l}\text { Faktor pendapatan masyarakat -> } \\
\text { Konsumsi air kemasan }\end{array}$ & 0,451 & 0,158 & 0,005 & Signifikan \\
$\begin{array}{l}\text { Faktor sosial budaya -> Konsumsi } \\
\text { air kemasan }\end{array}$ & 0,408 & 0,114 & 0,000 & Signifikan \\
\hline
\end{tabular}

Sumber: Hasil Pengolahan SEM PLS

Berdasarkan uji kecocokan model struktural diketahui bahwa faktor demografi, faktor pendapatan masyarakat, dan faktor sosial budaya berpengaruh signifikan terhadap konsumsi air kemasan di Indonesia. Ketiga variabel tersebut dapat menjelaskan sekitar 73 persen dari model yang terbentuk $\left(R^{2}=72,9 \%\right)$.

Perubahan demografi yang terjadi meliputi kelahiran, kematian, dan migrasi. Indonesia termasuk salah satu negara yang memiliki tingkat perubahan demografi yang tinggi dibandingkan negara-negara lain di dunia. Jumlah penduduk Indonesia menempati peringkat keempat didunia setelah Cina, India, dan Amerika Serikat (Worldometers, 2019). Jumlah penduduk Indonesia pada tahun 2019 diperkirakan sebanyak 269,1 juta jiwa. Dari sisi laju pertumbuhan penduduk, Indonesia juga tergolong tinggi. Laju pertumbuhan tahun 2018 mencapai 1,33 persen dimana melebihi laju pertumbuhan penduduk dunia yang hanya berkisar 1,1 persen. Dengan jumlah dan pertumbuhan penduduk yang tinggi, konsumsi penduduk Indonesia juga akan semakin tinggi. Termasuk konsumsi air kemasan. Hal tersebut yang harus menjadi perhatian. Semakin meningkatnya jumlah konsumsi air kemasan maka semakin meningkat pula ketergantungan masyarakat terhadap sumber air yang tidak berkelanjutan. Kebutuhan air yang merupakan hajat hidup orang banyak nantinya malah dikendalikan oleh kondisi pasar. Pengendalian laju pertumbuhan penduduk dapat menjadi solusi efektif untuk menekan ketergantungan terhadap air kemasan.

Selain pertumbuhan penduduk, urbanisasi juga ikut mendorong tingginya konsumsi air kemasan. Urbanisasi mengakibatkan semakin padatnya penduduk perkotaan. Kepadatan penduduk yang tinggi cenderung memberikan dampak buruk terhadap lingkungan. Diantaranya yaitu pencemaran sumber air. Tercemarnya sumber air menjadikan air kemasan sebagai pilihan bagi masyarakat. Mereka beranggapan bahwa mengonsumsi air kemasan lebih sehat ketimbang air yang bersumber dari lingkungan sekitar. 
Perubahan pada pendapatan masyarakat juga ikut berpengaruh terhadap konsumsi air kemasan. Masyarakat dengan pendapatan yang tinggi akan mengalokasikan konsumsinya terhadap barang/ jasa yang lebih bervariasi. Salah satunya adalah konsumsi air kemasan. Semakin tinggi pendapatan masyarakat maka semakin tinggi pula konsumsi air kemasan. Konsumsi tersebut dianggap sebagai salah satu gaya hidup yang harus dilakukan oleh masyarakat dengan pendapatan tinggi. Perspektif masyarakat yang beranggapan bahwa air kemasan lebih sehat membentuk pola gaya hidup tersebut.

Perspektif masyarakat terbentuk dari kondisi sosial budaya mereka. Salah satunya adalah dari informasi yang didapat. Anggapan air kemasan yang lebih sehat dibandingkan dengan sumber air lainnya merupakan jargon iklan produk-produk air kemasan di tv. Lebih dari 90 persen masyarakat Indonesia menonton tv. Kebiasaan tersebut menjadikan tv sebagai salah satu media propaganda yang masif. Semua iklan air kemasan menonjolkan higienitas sebagai kunci utama dari produknya. Kehigienisan tersebut digadang-gadang mampu menunjang kesehatan seseorang dengan lebih baik. Hal itulah yang tertanam di pikiran masyarakat. Sehingga semakin tinggi persentase penduduk yang menonton tv di suatu wilayah maka semakin tinggi pula persentase konsumsi air kemasan.

Kondisi sosial budaya yang juga mendorong konsumsi air kemasan adalah kualitas sumber daya manusia (SDM) di wilayah tersebut. Masyarakat dengan SDM tinggi memiliki akses informasi yang lebih luas dan merupakan pasar yang potensial untuk air kemasan. Kualitas SDM diukur melalui IPM sehingga dapat digambarkan bahwa wilayah dengan IPM yang tinggi maka konsumsi air kemasannya juga lebih tinggi.

Berdasarkan penjelasan di atas maka dapat disimpulkan bahwa ketiga variabel dalam penelitian (faktor demografi, faktor pendapatan masyarakat, dan faktor sosial budaya) berpengaruh positif terhadap perkembangan konsumsi air kemasan di Indonesia. Berdasarkan hasil Smart PLS 3.0 nilai $Q^{2}$ menunjukkan angka 0,729 yang mengindikasikan bahwa model dapat digunakan untuk memprediksi suatu fenomena. Hasil pemodelan struktural yang terbentuk adalah:

Konsumsi air kemasan $=$ 0,334 faktor demografi $+0,451$ faktor pendapatan masyarakat $+0,408$ faktor sosial budaya + galat

Berdasarkan skor yang terbentuk dari model struktural SEM PLS tersebut diperoleh prediksi 5 provinsi dengan potensi konsumsi air kemasan terbesar di Indonesia yaitu: DKI Jakarta, Kepulauan Riau, Kalimantan Timur, Kalimantan Utara, dan Kepulauan Bangka Belitung.

\section{SIMPULAN}

Pola konsumsi air kemasan di Indonesia dipengaruhi oleh tiga faktor yaitu: faktor demografi, faktor pendapatan masyarakat, dan faktor sosial budaya. semakin tinggi tingkatan ketiga faktor tersebut maka semakin tinggi pula nilai konsumsi air kemasan di suatu wilayah. Faktor demografi dipengaruhi oleh pertumbuhan penduduk dan urbanisasi. Faktor pendapatan masyarakat tergambarkan lewat pengeluaran per kapita per bulan, sedangkan faktor sosial budaya 
dicerminkan melalui kebiasaan menonton tv masyarakatnya dan kualitas IPM.

Berdasarkan ketiga faktor tersebut, wilayah yang diprediksi akan menjadi wilayah dengan peningkatan konsumsi air kemasan terbesar yaitu provinsi: DKI Jakarta, Kepulauan Riau, Kalimantan Timur, Kalimantan Utara, dan Kepulauan Bangka Belitung.

Provinsi-provinsi tersebut harus menyiapkan solusi yang tepat dalam mengontrol perkembangan konsumsi air kemasan yang notabene bukan merupakan sumber air minum yang berkelanjutan. Hal yang dapat dilakukan diantaranya adalah: pengendalian pertumbuhan penduduk, pengendalian urbanisasi, dan edukasi terhadap masyarakat mengenai sumber air minum yang layak. Edukasi dilakukan supaya masyarakat paham bahwa sumber air yang layak tidak hanya berasal dari air kemasan, tetapi juga bisa berasal dari air leding eceran/ meteran, air hujan, dan pompa/ sumur/ mata air terlindung asalkan diolah dengan cara yang benar. Sehingga kebutuhan air masyarakat dapat dipenuhi dengan baik, tidak tergantung dari air kemasan yang lebih condong sebagai komoditas perdagangan.

\section{DAFTAR PUSTAKA}

Chen et al. (2012). Change of water consumption and its potential influential factors in Shanghai: A cross-sectional study. Shanghai: BMC.

Delina, P.J.E dan S. Dasinaa. (2016). Consumer Perception and Factors Influencing in Adapting of Bottled Water Consumption in Batticola District, Srilanka. International Journal of Interdisciplinary Research Methods. (3.4). 1-13.

Hair et al. (2011). An assessment of the use of partial least squares structural equation modeling in marketing research. Diakses 10 Agustus, 2020, dari http://www.researchgate.net

Hair et al. (2014). Partial least squares structural equation modeling (PLS-SEM). European Business Review, 26, 106-121. Diakses 6 Juli, 2020, dari https://www.emerald.com/insight/content

Jaya, I Gede Nyoman Mindra dan Sumertajaya, I Made. (2008). Pemodelan Persamaan Struktural Dengan Partial Least Square. Seminar Matematika dan Pendidikan Matematika. Bandung: UNPAD.

Jones et al. (2007). Drinking water consumption patterns in Canadian. Jurnal Water and Health, 10.1, 69-86. Diakses 23 Juli, 2020 dari: http://www.researchgate.net/publication

Joniansyah. (2018). Polisi Ungkap Pemalsuan Produk Air Mineral Merek Terkenal. Jakarta: Tempo.

Lowr, Paul Benjamin dan Gaskin, James. (2014). Partial Least Squares (PLS) Structural Equation Modeling (SEM) for Building and Testing Behavioral Causal Theory: When to Choose It and How to Use It. IEEE Transaction on Professional Communication. 57(2). 123-146.

Mosler et al. (2010). Personal, social, and situational factors influencing the consumption of drinking water from arsenic-safe deep tubewells in Bangladesh. Journal of Environmental Management. 91(6). 1316-23. 
Pintar et al. (2009). Water consumption habits of a south-western Ontario community. Jurnal Water and Health. 07(2). 276-292.

Regmi, Anita dan Dyck, John. (2015). Effects of urbanization on global Food Demand.Changing Structure of Global Food Consumption and Trade, 1.1, 23-30. Diakses 31 Maret, 2020 dari http:// https://www.ers.usda.gov/webdocs

Stoler et al. (2015). Piped water flows but sachet consumption grows: The paradoxical drinking water landscape of an urban slum in Ashaiman, Ghana. Habitat International. (47). 52-60. 